\title{
Snails from heavy-metal polluted environments have reduced sensitivity to carbon dioxide-induced acidity
}

\author{
Hugh Lefcort ${ }^{1 *}$, David A Cleary², Aaron M Marble ${ }^{1}$, Morgan V Phillips ${ }^{1}$, Timothy J Stoddard ${ }^{1}$, Lara M Tuthill ${ }^{1}$ \\ and James R Winslow ${ }^{1}$
}

\begin{abstract}
Anthropogenic atmospheric $\mathrm{CO}_{2}$ reacts with water to form carbonic acid $\left(\mathrm{H}_{2} \mathrm{CO}_{3}\right)$ which increases water acidity. While marine acidification has received recent consideration, less attention has been paid to the effects of atmospheric carbon dioxide on freshwater systems - systems that often have low buffering potential. Since many aquatic systems are already impacted by pollutants such as heavy metals, we wondered about the added effect of rising atmospheric $\mathrm{CO}_{2}$ on freshwater organisms. We studied aquatic pulmonate snails (Physella columbiana) from both a heavy-metal polluted watershed and snails from a reference watershed that has not experienced mining pollution. We used gaseous $\mathrm{CO}_{2}$ to increase water acidity and we then measured changes in antipredatory behavior and also survival. We predicted a simple negative additive effect of low $\mathrm{pH}$. We hypothesized that snails from metal-polluted environments would be physiologically stressed and impaired due to defense responses against heavy metals. Instead, snails from populations that acclimated or evolved in the presence of heavy metal mining pollution were more robust to acidic conditions than were snails from reference habitats. Snails from mining polluted sites seemed to be preadapted to a low pH environment. Their short-term survival in acidic conditions was better than snails from reference sites that lacked metal pollution. In fact, the $48 \mathrm{~h}$ survival of snails from polluted sites was so high that it did not significantly differ from the $24 \mathrm{~h}$ survival of snails from control sites. This suggests that the response of organisms to a world with rising anthropogenic carbon dioxide levels may be complex and difficult to predict. Snails had a weaker behavioral response to stressful stimuli if kept for 1 month at a pH that differed from their lake of origin. We found that snails raised at a pH of 5.5 had a weaker response (less of a decrease in activity) to concentrated heavy metals than did snails raised at their natal pH of 6.5. Furthermore, snails raised a pH of 5.5, 6.0, and 7.0 all had a weaker antipredatory response to an extract of crushed snail cells than did the $\mathrm{pH} 6.5$ treatment snails.
\end{abstract}

Keywords: Snails, Carbon dioxide, Climate change, Heavy metals, Behavior

\section{Background}

It has long been recognized that atmospheric pollutants and contact with mining wastes could impact aquatic habitats (Literary Digest 1926; Berl 1934; Ellis 1940). During the 1970's and 1980's it was thought that the main cause of atmospheric pollution was nitric and sulfuric acid formation due to the burning of fossils fuels

\footnotetext{
*Correspondence: lefcort@gonzaga.edu

${ }^{1}$ Biology Department, Gonzaga University, 502 E. Boone Avenue,

Spokane, WA 99258, USA

Full list of author information is available at the end of the article
}

(Schindler et al. 1985). By the first part of the twenty-first Century it began to be apparent that massive anthropogenic atmospheric carbon dioxide inputs could also affect the oceans by increasing water acidity (Caldeira and Wickett 2003). Since then a large body of literature has developed that document these effects on marine biota (extensively reviewed in Feely et al. 2012). What have received less attention are the effects of atmospheric carbon dioxide on aquatic systems.

Atmospheric $\mathrm{CO}_{2}$ levels have risen from $280 \mathrm{ppm}$ in the year 1800 to around $400 \mathrm{ppm}$ today which are higher than levels in the last 800,000 years (IPCC 2007).

\section{Springer}


Although nutrients can cause the growth of autotrophs which can lower $\mathrm{CO}_{2}$ levels (Hickey and Banas 2003), and although atmospheric $\mathrm{CO}_{2}$ levels have been much higher several times over the last 300 million years, they have not risen at such a rapid rate. A slow rise allows natural events like the weathering of rocks to buffer the change but today's brisk rise can overtake these processes (Archer et al. 1997). This rise may affect gastropods which form the basis of many aquatic food chains.

Carbon dioxide increases water acidity by:

$\mathrm{CO}_{2(\mathrm{~g})} \rightleftarrows \mathrm{CO}_{2(a q)}+\mathrm{H}_{2} \mathrm{O}_{(l)} \rightleftarrows \mathrm{H}_{2} \mathrm{CO}_{3(a q)} \rightleftarrows \mathrm{H}_{(a q)}^{+}+\mathrm{HCO}_{3(a q)}^{-}$

and

$$
\mathrm{H}_{(a q)}^{+}+\mathrm{CO}_{3(a q)}^{2-} \rightleftarrows \mathrm{HCO}_{3(a q)}^{-}
$$

Atmospheric $\mathrm{CO}_{2}$ reacts with water to form carbonic acid $\left(\mathrm{H}_{2} \mathrm{CO}_{3}\right)$. Carbonic acid then dissociates into a hydrogen ion $\left(\mathrm{H}^{+}\right)$, and bicarbonate, $\mathrm{HCO}_{3}{ }^{-}$. Some of the $\mathrm{H}^{+}$released by the carbonic acid reacts with carbonate $\left(\mathrm{CO}_{3}{ }^{2-}\right)$ that is already in the water to form more bicarbonate. This loss of carbonate is serious because many gastropods use it to build shells of calcium carbonate $\left(\mathrm{CaCO}_{3}\right)$. The rise in acidity reduces the saturation state of aragonite which is a biomineral of calcium carbonate (Caldeira and Wickett 2003; Orr 2005; Feely et al. 2012). Once the saturation state drops below a certain level gastropods shells are thermodynamically favored to corrode. The animals can overcome this loss of shell thickness but only by using an energetically expensive process to lay material onto the inner surface of the shell (Fabry et al. 2008). Contrarily, a rise in water temperature makes $\mathrm{CO}_{2}$ less soluble in water (Feely et al. 2012). In addition, dissolution of shells is also affected by species specific protective organic coatings on shells, trace element components, and the microstructure of the shell (Feely et al. 2009).

Many marine organism exhibit impaired growth and development under high $\mathrm{pCO}_{2}$ levels. For example, Northern Abalone (Haliotis kamtschatkana) is a marine gastropod that experiences deformed larval morphology when raised under an atmosphere of $800 \mathrm{ppm} \mathrm{pCO}_{2}$ (Crim et al. 2011). Several studies have found impaired growth of mussels (Mytilus) under high $\mathrm{pCO}_{2}$ conditions (Gaylord et al. 2011; Gazeau et al. 2011) but two metaanalyses of molluscs (Hendriks et al. 2010; Kroeker et al. 2010) did not find a $\mathrm{pCO}_{2}$ effect on growth. Furthermore, in some oysters the effect of elevated water acidity on growth and survival is ameliorated in the second generation (Feely et al. 2009).

Marine organism under high $\mathrm{pCO}_{2}$ levels also exhibit behavioral alterations. Acidic water makes hermit crabs more risk adverse (de la Haye et al. 2011) and impairs the ability of hermit crabs (de la Haye et al. 2012) and reef fishes (Dixson et al. 2010, 2012) to detect chemical alarm cues. Conch snails exhibit a reduced ability to "leap" backwards when confronted by cone shell predators (Watson et al. 2014).

The effects of atmospheric $\mathrm{CO}_{2}$ on freshwater are less well known since most studies of freshwater acidity concerned nitric acid and sulfuric acid caused acid rain (Økland and Økland 1986; Mason 1992; Korsman 1999; Lacoul et al. 2011). In these studies some pulmonate snails exhibit sensitivities below a pH of only 6.25 (Holcombe et al. 1984) but others have found an Amnicolid freshwater snail that was robust to short-term exposure of nitric acid with a pH of 4.0 (Servos and Mackie 1986).

In addition to direct physiological effects (Økland and Økland 1979) acidic water can impact predator/ prey interactions (Lippert et al. 2007) in a wide range of taxa. Acid water impairs the ability of juvenile freshwater salmon (Leduc et al. 2006, 2009) to detect and avoid fish predators, and rainbow trout (Brown et al. 2012) fail to detect chemical alarm cues. In addition, acidic water negatively impacts the ability of beetles to use temperature changes to moderate diving behavior (Calosi et al. 2007) and pulmonate snails are more common in alkaline streams (Dillon and Benfield 1982). High alkalinity can have a similar effect in that at pH 7.5 Physa acuta snails respond to fish cues by moving into safer habitats, but avoidance becomes impaired at a pH of 9.4 (Turner and Chislock 2010).

\section{Metal pollution}

Anthropogenic influences rarely occur alone; along with $\mathrm{CO}_{2}$ rises, organisms also are affected by co-occurring pollutants such as heavy metals. Increasingly, researchers are beginning to look at the synergistic, antagonistic, and additive effects of multiple stressors (Heugens et al. 2001, Coors and De Meester 2008) especially $\mathrm{CO}_{2}$ induced climate effects (Noyes et al. 2009; Hooper et al. 2013; Moe et al. 2013). Acidity may alter the solubility of metals and increase their toxicity when in a dissolved state since metals tend to be more harmful in soft water (Hunter 1980; Feely et al. 2012). In waters with low alkalinity, acidification increased the toxicity of copper to larval fathead minnow (Welsh et al. 1993). Yet the reverse is also observed. Dissolved zinc is more lethal to rainbow trout when the water has a higher $\mathrm{pH}$ and lower hardness levels (Bradley and Sprague 1985). Furthermore, in a test of an amphipod, the toxicity of cadmium and zinc was greatest at $\mathrm{pH} 8.3$ and least at $\mathrm{pH} 6.3$ while the toxicity of lead was greatest at pH 6.3 and least at $\mathrm{pH} 8.3$ (Schubauer-Berigan et al. 1993).

One area where the combined impacts of $\mathrm{CO}_{2}$-induced acidity and metal pollution may be observed is in the 
Silver Valley of northern Idaho, USA. For over 130 years pollution from mine tailings have been released into the environment (Neufeld 1987; Farag et al. 1998; Sprenke et al. 2000). Metals such as lead, zinc, cadmium, and arsenic are patchily distributed in downstream lakes (Ellis 1940; Rabe and Bauer 1977; Ridolfi Engineering 1993). The lakes have been contaminated for over 125 years and hence at least 125 snail generations (Hunter 1975; Lefcort et al. 2010) have undergone selective pressures due to heavy metals.

Our lab examines how aquatic snails (Physella columbiana) avoid patchy distributions of heavy metal pollution while also balancing the need to avoid predation (Lefcort et al. 1999, 2002, 2008). We study snails from both a heavy metal polluted watershed and snails from a reference watershed that has not experienced mining. Snails are a good model for study because they are a major component of the metal-impacted food chains. Snails have contact with bottom sediments and they are a preferred food for centrarchids and salmonids fishes (Ellis 1940).

These snails alter their behavior when exposed to kairomones released from crushed snail cells which are an indicator of predation (von Frisch 1938; Atema and Stenzler 1977; Dickey and McCarthy 2007). Upon detection the snails reduce their movements and pull into their shells (Lefcort et al. 2000). Metals stress the snails and impair this response (Lefcort et al. 2000).

Since anthropogenic $\mathrm{CO}_{2}$ is rising we wanted to revisit some of the work done in the 1970's and 1980's concerning acid rain while looking at a new stressor-carbonic acid. Specifically, does $\mathrm{CO}_{2}$-induced water acidity have different effects than nitric acid or sulfuric acid-induced water acidity? Also how does a new toxicant, $\mathrm{CO}_{2}$, affect the survivability and antipredatory behavior of organisms that exist in an ecosystem already polluted by heavy metal mining waste? Are the effects of metals and acidity additive or does one ameliorate the other? We predicted that:

1. P. columbiana snails from heavy metal lakes would exhibit lower survivability at low pH levels (4.5 and 5.0) than snails from reference lakes.

2. When raised in $\mathrm{CO}_{2}$-induced low $\mathrm{pH}$ aquatic environments, the snails would exhibit reduced antipredatory and metal avoidance behaviors.

\section{Methods}

\section{Experiment 1: $\mathrm{LD}_{50}$}

We first examined the lethality of $\mathrm{CO}_{2}$-induced acidity to two groups of snails; snails from reference sites and snails from sites of known heavy metal pollution. Water acidity and levels of metals in snails from these sites are shown in Table 1.
Table 1 Metal levels $(\mathrm{mg} / \mathrm{kg})$ of dried unshelled snails used in tests and $\mathrm{pH}$ of lakes $(\mathrm{X} \pm \mathrm{SD}$ )

\begin{tabular}{lllll}
\hline & Cadmium & Lead & Zinc & pH \\
\hline Reference lakes & & & & \\
Areush & $*$ & $*$ & 4.48 & $7.3(0.4)$ \\
Badger & $*$ & 0.53 & 5.78 & $7.0(0.4)$ \\
Bayit & $*$ & $*$ & $*$ & $7.1(0.3)$ \\
Deer & $*$ & 0.63 & 14.10 & $6.7(0.4)$ \\
Hauser & $*$ & $*$ & 8.10 & $6.9(0.2)$ \\
Hick & $*$ & $*$ & 4.93 & $7.2(0.2)$ \\
Mecca & $*$ & $*$ & 2.33 & $7.0(0.1)$ \\
Worm & $*$ & 1.30 & 6.29 & $6.8(0.4)$ \\
Williams & $*$ & $*$ & 5.35 & $7.0(0.3)$ \\
Metal polluted lakes & & & \\
Anderson & $*$ & 5.59 & 11.20 & $7.3(0.5)$ \\
Bull Run & $*$ & 7.15 & 24.80 & $7.0(0.4)$ \\
Farm & $*$ & $*$ & 14.15 & $6.7(0.3)$ \\
Goose & $*$ & $*$ & 14.35 & $7.1(0.2)$ \\
Killarney & $*$ & 0.71 & 15.86 & $7.1(0.3)$ \\
Mile 109 & $*$ & $*$ & 13.81 & $7.2(0.2)$ \\
Mile 109.5 & $*$ & $*$ & 14.66 & $7.2(0.4)$ \\
Porter & $*$ & 1.29 & 16.65 & $6.9(0.4)$ \\
Rose & $*$ & 7.37 & 34.56 & $6.9(0.3)$ \\
Thompson & & 5.53 & 10.60 & $6.9(0.5)$ \\
\hline Besto & & $* .79$ & &
\end{tabular}

* Below detection limits Cd 0.35 mg $/ \mathrm{kg}, \mathrm{Pb} 0.51 \mathrm{mg} / \mathrm{kg}, \mathrm{Zn} 0.44 \mathrm{mg} / \mathrm{kg}$.

We measured the lethal dose of acidity that killed 50\% of the population. During June of 2014 we collected $P$. columbiana snails from nine reference lakes and 10 heavy metal polluted lakes. All lakes were along the NE Washington State/NW Idaho State border and were of similar ecological parameters (Lefcort et al. 2000). Thirty snails from each lake were collected and divided into individual $200 \mathrm{~mL}$ cups kept at two different levels of acidity by bubbling in $\mathrm{CO}_{2}: \mathrm{pH} 4.5$ and $\mathrm{pH}$ 5.0, for a total of 570 cups. A pH of 4.5 is equivalent to an atmospheric $\mathrm{CO}_{2}$ level of $100,000 \mathrm{ppm}$ while a $\mathrm{pH}$ of 5.0 is equivalent to $10,000 \mathrm{ppm}$. Preliminary experiments had shown that all animals died within $12 \mathrm{~h}$ at $\mathrm{pH} 4.0$ and all animals survived for $72 \mathrm{~h}$ at $\mathrm{pH} 6.5$. The $\mathrm{pH}$ of the cups was kept in a range of $\pm 0.3 \mathrm{pH}$ by changing the water every $3 \mathrm{~h}$. No food was provided. The snails were monitored for $48 \mathrm{~h}$, and were marked dead or alive at each hour. An Accumet AB200 pH/Conductivity meter by Fisher Scientific was used to measure $\mathrm{pH}$.

\section{Metal analysis}

Snail tissues were first dissolved in trace metal grade nitric acid (Sigma-Aldrich Co.) using a CEM brand microwave dissolution (model MDS-2100) system. The solubilized material from snails was then diluted with 
distilled water and analyzed by Inductively Coupled Plasma Optical Emission Spectrometer and Graphite Furnace Atomic Absorption. All preparations and tests were performed by Anatek Labs Spokane, WA, USA.

\section{Experiment 2: avoidance and activity}

Next we explored the effects of acidic rearing regimes on snail behavior. We raised the snails at four different levels of acidity and then we measured their ability to avoid heavy metals and an index of predation.

\section{Rearing snails}

We conducted experiments on snails from Bayit Pond, Spokane County, WA, USA). Bayit Pond is a reference pond $\left(128 \mathrm{~m}^{2}\right)$ that is free of heavy metals and has a mean $( \pm \mathrm{SE}) \mathrm{pH}$ of 6.87 (0.24). It was constructed in 2003 and stocked with snails from Coeur d'Alene Basin lakes in 2008.

In May of 2013 two hundred snails were brought into our lab at Gonzaga University and housed in a 40-L aquaria filled with artificial pond water (deionized water, $\mathrm{CaCl}_{2}, \mathrm{~K}_{2} \mathrm{HPO}_{4}$, and $\mathrm{MgSO}_{4}$ that resulted in water properties of calcium $4.84 \mathrm{mg} / \mathrm{L}$, chloride $3.52 \mathrm{mg} / \mathrm{L}$, and conductivity of $48.6 \mu \mathrm{mhos} / \mathrm{cm})$. All were fed lettuce and none were reared with heavy metals. Water was changed twice weekly. Fifty animals were raised for 1 month at either $\mathrm{pH} 7.0,6.5$. 6.0 or 5.5 . In preliminary experiments we also used a pH 5.0 treatment but few animals survived.

\section{Controlling $\mathrm{pH}$}

Filtered beverage grade pure carbon dioxide (OXARC, Spokane, WA, USA) was filtered and then bubbled through an air stone to reduce the $\mathrm{pH}$ of certain treatments (the $\mathrm{pH} 7.0$ treatment was bubbled with atmospheric air). The $\mathrm{CO}_{2}$ was kept at a constant pressure of approximately $100 \mathrm{kPa}$ and added to the tubs for differing amounts of time, twice a day until the desired $\mathrm{pH}$ was attained. This kept the $\mathrm{pH}$ in a range of $\pm 0.3 \mathrm{pH}$ units. A similar diurnal variation in $\mathrm{pH}$ also naturally occurs at our field sites (Lefcort unpubl.).

It was difficult to achieve a $\mathrm{pH}$ of 7.0 since un-buffered water exposed to ambient laboratory conditions interacted with high anthropogenic levels of atmospheric $\mathrm{CO}_{2}$ and equilibrated at $\sim \mathrm{pH} 6.5$. Therefore we buffered each tub using Tetra $\mathrm{pH} 7.0$ tablets which is composed primarily of sodium bicarbonate. In ponds, the normal dissolution of naturally occurring buffers, such as limestone, results in natural bicarbonate which has the same effect. The artificial pond water solution plus the Tetra tablet resulted in water properties of calcium $5.74 \mathrm{mg} / \mathrm{L}$, chloride $30.7 \mathrm{mg} / \mathrm{L}$, sodium $76.6 \mathrm{mg} / \mathrm{L}$, and conductivity of $232.0 \mu \mathrm{mhos} / \mathrm{cm}$.

\section{Preparation of metal solutions}

We prepared heavy metal soil stock solution by stirring one liter of vigorously rinsed soil from a river bank within the Bunker Hill Superfund site in northern Idaho State (Lefcort et al. 1999), into a container of $40 \mathrm{~L}$ of deionized water. After letting the solution settle for $48 \mathrm{~h}$ we poured off the supernant and filtered it. After dilutions this resulted in a concentration of $2.1 \mu \mathrm{g} / \mathrm{L}$ of cadmium, 6,500.0 $\mu \mathrm{g} / \mathrm{L}$ of zinc, $105.6 \mu \mathrm{g} / \mathrm{L}$ of lead, and minor amounts of other metals (Anatek Labs, Spokane, WA, USA using inductively coupled plasma mass spectrometry and graphite furnace atomic absorption). Dilutions were then made with artificial pond water. For all experiments pond water was freshly prepared on the day of testing.

\section{Preparation of crushed-snail extract}

We produced snail extract (an inducer of a fright response, Lefcort et al. 2000, 2013) by first slowly cooling a snail $(0.4-0.6 \mathrm{~g})$ to $3^{\circ} \mathrm{C}$ in a dish of pond water. The animal was then macerated with $50 \mathrm{~mL}$ of DI water. One drop of this extract was used in $2 \mathrm{~L}$ of test solution. No anesthesia other than cooling was used to avoid introducing novel chemical cues (approved by Gonzaga Institutional Animal Care and Use Committee).

\section{Testing snails}

Twenty-five snails from each of the four $\mathrm{pH}$ rearing levels were tested using a behavioral assay previously used in our lab (Lefcort et al. 2013). A $15 \mathrm{~cm}$ diameter circular glass dish (Figure 1) was divided into four equal sized zones. The dish was covered in a thin layer of pre-washed sand and artificial pond water. A snail was placed in the middle of the dish, on the midline between zones 2 and 3 . At each minute, for $20 \mathrm{~min}$, the snail's zone was recorded to determine if the snail moved away from the stimulus (scored as avoidance). Each snail was used for three tests (in three separate dishes) in the following order: control-with no added stimulus,

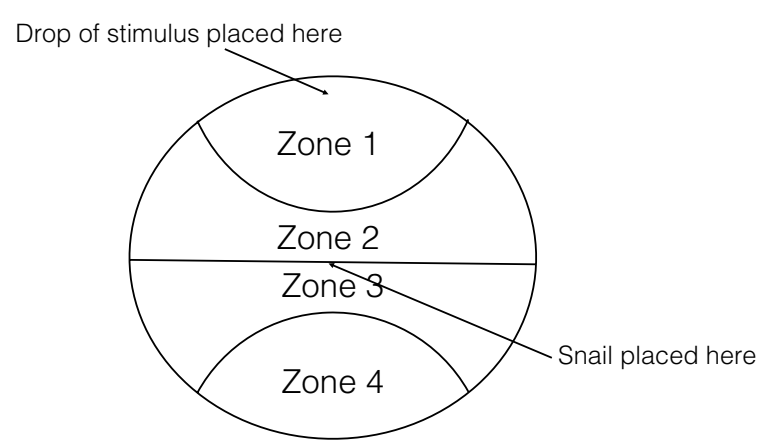

Figure 1 Avoidance dish used in Experiment 2. 
extract-using a drop of snail extract in zone 1, and heavy metal avoidance-using a drop of heavy metal solution in zone 1.

Snails were rested between treatments one and two, and between two and three for $60 \mathrm{~min}$ in a dish of pond water. Individual snails were only tested in a single set of experiments. This was done to prevent any effects of learning. Previous experiments (Lefcort et al. 2013) showed that repeated trials of the same treatment did not alter individual snail responses, i.e., there was no time effect, and the order of stimuli was not significant as long as 60 min elapsed between trials. The dishes were washed with hot water and wiped dry with paper towels between animal replicates and the sand was changed.

\section{Statistical tests}

Probit analysis (Finney 1947) was used to determine calculated $\mathrm{LD}_{50}$ values in Experiment 1 followed by Student's $t$ tests and one-way analysis of variance followed by Newman-Keuls multiple comparisons. Kruskal-Wallis one-way analysis of variance by ranks was used in Experiment 2 after nonparametric adjusted rank transform tests (Leys and Schumann 2010) indicated no significant interaction terms. Alpha was set to 0.05 .

\section{Results}

\section{Experiment 1: $\mathrm{LD}_{50}$}

Survivorship values (based on hydrogen ion levels) are displayed in Figure 2. Snails from heavy-metal polluted ponds had higher survival than snails from reference ponds. This occurred at both $24 \mathrm{~h}(\mathrm{t}=2.43 \mathrm{df}=17$, $\mathrm{P}=0.032)$ and $48 \mathrm{~h}(\mathrm{t}=3.47, \mathrm{df}=17, \mathrm{P}=0.003)$. The $48 \mathrm{~h}$ survival of snails from polluted sites was so high

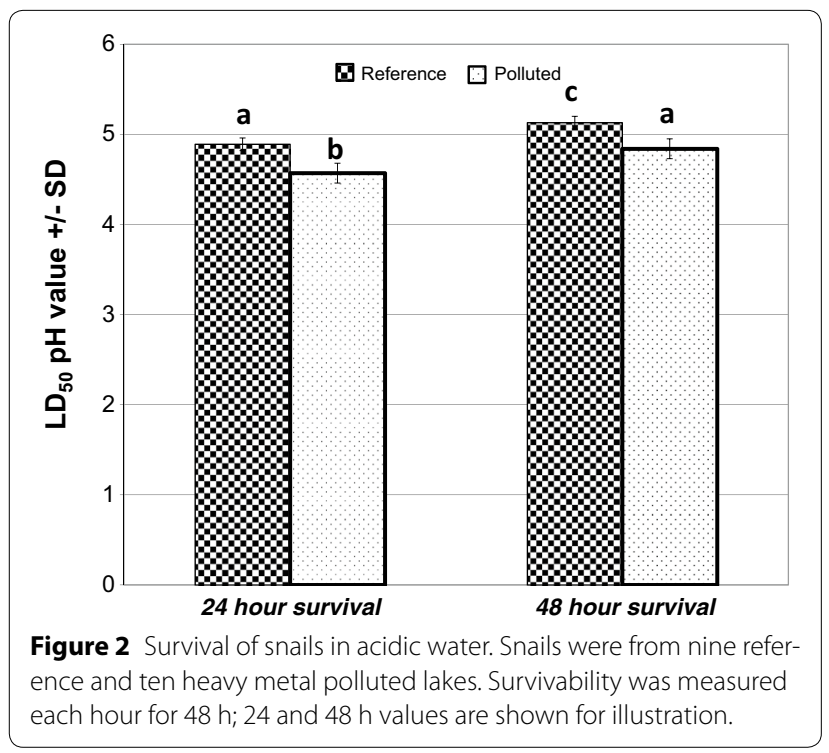

that it not significantly differ from the $24 \mathrm{~h}$ survival of snails from control sites (one-way ANOVA $\mathrm{F}_{3,36}=8.85$, $\mathrm{P}<0.001$, Newman-Keuls multiple comparisons $\mathrm{P}<0.05)$. Acidity values of metal-polluted and reference lakes did not differ $(t=1.45, \mathrm{df}=17, \mathrm{P}=0.608)$. For unknown reasons one reference lake, Deer Lake, had high zinc levels. We included this lake in the above analyses but the results were similar when it was excluded.

\section{Experiment 2A: movement, activity in relation to stimulus}

The response of the animals to metal solutions (KruskalWallis $\mathrm{H}=9.62, \mathrm{df}=3, \mathrm{p}=0.023)$ and crushed-snail extract (Kruskal-Wallis $\mathrm{H}=20.28, \mathrm{df}=3, \mathrm{p}<0.001$, Figure 3) were both impaired if the snails were raised at a $\mathrm{pH}$ that was closer to their natal acidity of roughly 6.5 (Figure 3). Animals had a stronger (less movement) response to both metals and snail extract if raised at a $\mathrm{pH}$ of 6.5. Snails raised at higher $\mathrm{pH}(7.0)$ or lower $\mathrm{pH}(6.0$ and 5.5 ) significantly decreased their movements (when compared to control water) but not as much as the snails raised at $\mathrm{pH} 6.5$.

\section{Experiment 2B: avoidance, location due to stimulus}

Water acidity did not alter the locations of the animals over the 20 min test period when exposed to metal stimulus (Kruskal-Wallis $\mathrm{H}=4.28, \mathrm{df}=3, \mathrm{p}=0.234$, Figure 4) nor snail extract (Kruskal-Wallis $\mathrm{H}=5.05, \mathrm{df}=3$, $\mathrm{p}=0.169$, Figure 4 ), i.e., rearing acidity did not increase or decrease the snails' natural avoidance of metals and extract.

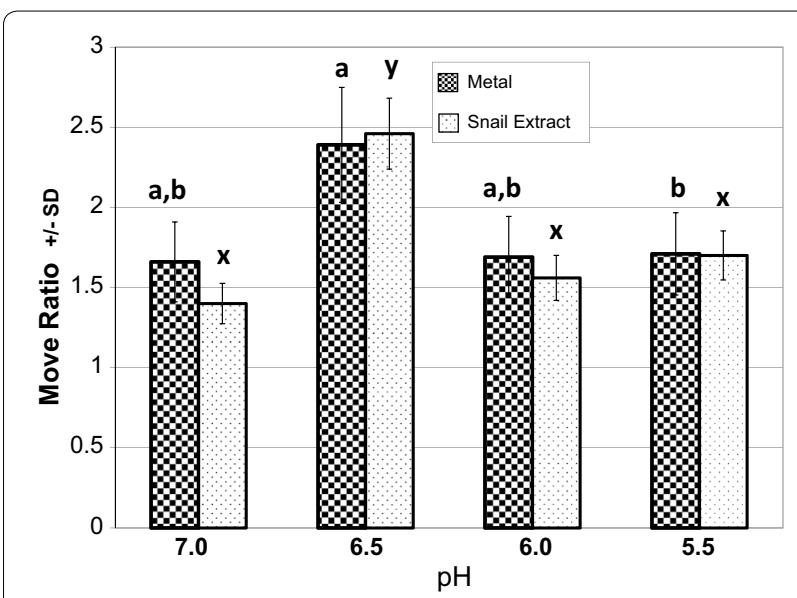

Figure 3 Movement and rearing $\mathrm{pH}$. The number of times each animal $(X \pm S D)$ crossed between zones was continuously recorded for $20 \mathrm{~min}$. Y values were calculated by dividing control stimulus (plain pond water) moves by the experimental stimulus (extract or metal) moves. Hence, $Y$ axis values above 1 indicate that the animal moved less during experimental treatments than under control conditions. Letters are Tukey multiple comparisons. Identical letters indicate no significant difference between values. 


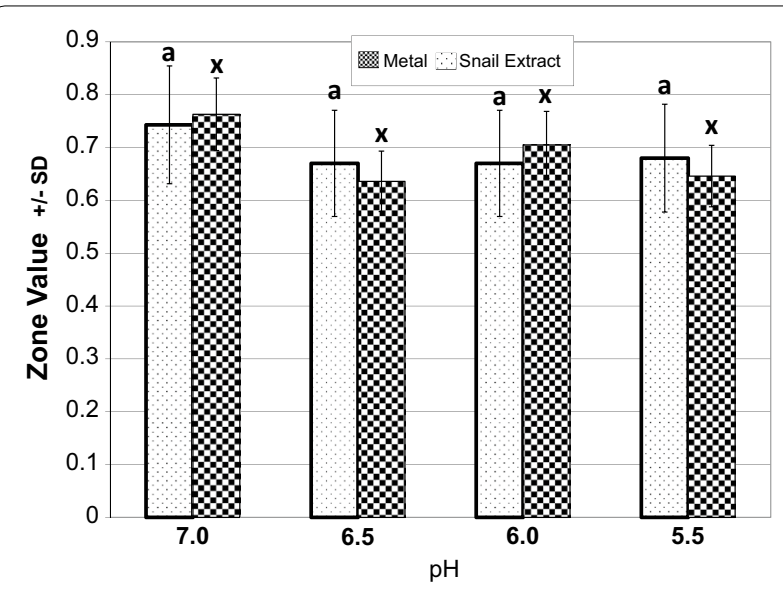

Figure 4 Avoidance and rearing $\mathrm{pH} . \mathrm{Y}$ axis (zone location) is determined by assigning a linear point value for each of eight zones. Zones close to the stimulus drop had low values and zones further away had higher values. Zones locations were recorded each minute for $20 \mathrm{~min}$. These 20 values were added to derive one number for control stimulus (pond water), one for extract, and one for metal stimulus. $Y$ values were calculated by dividing control stimulus value by the experimental stimulus (extract or metal) value. Hence, $Y$ axis values below 1 indicate that the experimental animals moved further away from the stimulus more than they had moved under control stimulus. Letters are Tukey multiple comparisons. Identical letters indicate no significant difference between values.

\section{Discussion}

We found that snails that evolved in the presence of heavy metal mining pollution were more robust to acidic conditions than were snails that had not evolved in the presence of heavy metals. This suggests that the response of organisms to a world with rising anthropogenic carbon dioxide levels may be more complex than once believed.

We predicted a simple negative additive effect of low $\mathrm{pH}$. We hypothesized that snails from metal-polluted environments would be physiologically stressed and impaired due to defense responses against heavy metals. What we found was that these snails seem to be preadapted to a low $\mathrm{pH}$ environment. Their short-term survival in acidic conditions (Experiment 1) was better than snails from reference sites that lacked metal pollution. In fact, the $48 \mathrm{~h}$ survival of snails from polluted sites was so high that it did not significantly differ from the $24 \mathrm{~h}$ survival of snails from control sites. The mechanism behind this result is unknown but it may be due to altered epithelium membrane permeability (Sullivan and Cheng 1975) or altered mucus secretion. Pedal mucus secretion by closely related Lymnaea stagnalis snails reduce the effects of aluminum exposure (Jugdaohsingh et al. 1998; Balance et al. 2001) but it is unknown if this would be protective in high acidity environments. Our reference site snails seem similar to a closely related Physid snail which exhibited sensitivities at pH values below 6.25 (Holcombe et al. 1984).
This is not to say that rising global atmospheric $\mathrm{CO}_{2}$ levels may not have an overall negative effect on snails. We also observed that snails had a weaker response to stressful stimuli if kept for 1 month at a $\mathrm{pH}$ that differed from their natal lake (Experiment 2). These snails were derived from a population inhabiting a heavy metal rich environment but they have spent the last five generations in a heavy metal-free pond whose $\mathrm{pH}$ annually ranges from 6.5 to 7.1 .

Molluscs may be quite susceptible to changes in water quality. Freshwater mussels experience oxidative damage when exposed to many of the component of urban runoff (Machado et al. 2014). In particular a drop in $\mathrm{pH}$ may pose particular challenges to gastropods and hence our results are similar to those of the 1970's and 1980's that examined the effects of acid rain (Økland and Økland 1979; Servos and Mackie 1986). For example marine abalone exposed to acidic waters have impaired feeding abilities as larvae (Vargas et al. 2013), and adults are less able to self-right themselves after dislodgement (Manríquez et al. 2013). Mussels have reduced phagocytic ability at higher acidity levels (Bibby et al. 2008).

Snails normally reduce their activity when exposed to an extract of crushed snail cells or when exposed to concentrated heavy metals (Lefcort et al. 2000, 2013). However we found that snails raised at a $\mathrm{pH}$ of $5.5 \mathrm{had}$ a weaker response (less of a decrease in activity) to concentrated heavy metals than did snails raised at a $\mathrm{pH}$ of 6.5. Furthermore, snails raised at a $\mathrm{pH}$ of 5.5, 6.0, and 7.0 all had a weaker response to an extract of crushed snail cells than did the $\mathrm{pH} 6.5$ treatment snails. In addition to a reduction of activity, snails also normally move away from a drop of heavy metal rich water or an extract of crushed snail cells (Lefcort et al. 2013). In this study we found that this avoidance response was not significantly affected by a 1 month exposure to an altered level of water acidity. Our results are similar to a study of mangrove-inhabiting periwinkles that moved away from acidified waters (pH 6.2-7.0, Amaral et al. 2014). One intertidal periwinkle normally produces thicker shells in the presence of crab predatory cues but this response is disrupted at low seawater $\mathrm{pH}$ (Bibby et al. 2007).

Yet the net effect of higher acidity levels is unclear. Acidic runoff in estuaries revealed no effects on crabs and only weak effects on bivalves and gastropods (Amaral et al. 2011). Indirect effects may also allow certain taxa to benefit from the impairment of competing taxa (Barry et al. 2013). Additionally, the effects of acidification on antipredatory responses have been found to be quite species specific among coral reef fishes (Ferrari et al. 2011). Even organisms as taxonomically distant from gastropods as freshwater diatoms, experience a nonadditive effect of heavy metals and acidity (Luís et al. 2014). These diatoms 
live in biofilms near the output of hardrock mines. Populations that have adapted to low $\mathrm{pH}$ conditions are less affected by copper and zinc effluents (Luís et al. 2014).

Given the behavioral effects of rising $\mathrm{CO}_{2}$ levels one solution may be to add lime to lakes to raise their $\mathrm{pH}$. Unfortunately this often just moves metal pollutants from the water column to sediments (Wällstedt and Borg 2005). Since snails often graze off of sediments, the liming of lakes may actually increase the body burden of metals which may transfer up food chains.

Our results illustrate the difficulty of predicting future effects of rising $\mathrm{CO}_{2}$ levels. $\mathrm{CO}_{2}$ induced effects add new stressors to already anthropomorphically perturbed system (Gouin et al. 2013; Manciocco et al. 2014) which requires the application of new modes of modelling since adaptions can alter the effects of multiple stressors (Fischer et al. 2013). The result of those added stressors may be non-additive and indirect (Coors and de Meester 2008).

In the future we plan on repeating our LD50 survival experiment with the added treatment of heavy metals. This way snails would be simultaneously challenged by two stressors. We also want to measure cellular and immunological responses. Pulmonate snails have metalsequestering metallothionein (Dallinger et al. 2001) which provide some tolerance to the toxicants. Perhaps metallothionein is impaired under conditions of hypercapnia.

\begin{abstract}
Authors' contribution
$\mathrm{HL}$ helped design the experiments, analyzed the data, wrote the manuscript, and conducted some of the LD50 tests. DC advised on water chemistry. AM, $\mathrm{MP}$, and LT conducted preliminary experiments and helped derive the methods. TS and JW collected animals and conducted most of the experiments. All authors read and approved the final manuscript.
\end{abstract}

\section{Author details}

1 Biology Department, Gonzaga University, 502 E. Boone Avenue, Spokane, WA 99258, USA. ${ }^{2}$ Chemistry Department, Gonzaga University, 502 E. Boone Avenue, Spokane, WA 99258, USA.

\section{Acknowledgements}

This study was funded by a Grant by the Gonzaga Science Research Program, Howard Hughes Medical Institute through the Undergraduate Science Education Program, and the Dr. Scholl Foundation.

\section{Compliance with ethical guidelines}

\section{Competing interests}

The authors declare that they have no competing interests.

Received: 21 March 2015 Accepted: 1 June 2015

Published online: 17 June 2015

\section{References}

Amaral V, Cabral H, Bishop M (2011) Resistance among wild invertebrate populations to recurrent estuarine acidification. Estuar Coast Shelf Sci 93:460-467
Amaral V, Cabral H, Bishop M (2014) Prior exposure influences the behavioural avoidance by an intertidal gastropod, Bembicium auratum, of acidified waters. Estuar Coast Shelf Sci 136:82-90

Archer DE, Kheshgi H, Maier-Reimer E (1997) Multiple timescales for neutralization of fossil fuel $\mathrm{CO}_{2}$. Geophys Res Lett 24:405-408

Atema J, Stenzler D (1977) Alarm substance of the marine mud snail, Nassarius obsoletus: Biological characterization and possible evolution. J Chem Ecol 3:173-187

Balance S, Phillips PJ, McCrohan CR, Powell JJ, Jugdaohsingh R, White KN (2001) Influence of sediment biofilm on the behaviour of aluminum and its bioavailability to the snail Lymnaea stagnalis in neutral freshwater. Can J Fish Aquat Sci 58:1708-1715

Barry J, Buck K, Lovera C, Brewer P, Seibel B, Drazen J et al (2013) The response of abyssal organisms to low pH conditions during a series of $\mathrm{CO} 2$-release experiments simulating deep-sea carbon sequestration. Deep-Sea Res Part II Top Stud Oceanogr 92:249-260

Berl E (1934) Origins of asphalts, oil, natural gas and bituminous coal. Science 80:227-228

Bibby R, Cleall-Harding P, Rundle S, Widdicombe S, Spicer J (2007) Ocean acidification disrupts induced defenses in the intertidal gastropod Littorina littorea. Biol Lett 3:699-701

Bibby R, Widdicombe S, Parry H, Spicer J, Pipe R (2008) Effects of ocean acidification on the immune response of the blue mussel Mytilus edulis. Aquat Biol 2(1):67-74

Bradley RW, Sprague JB (1985) The influence of pH, water hardness, and alkalinity on the acute lethality of zinc to rainbow trout (Salmo gairdneri). Can J Fish Aquat Sci 42:731-736

Brown GE, Elvidge CK, Ferrari MO, Chivers DP (2012) Understanding the importance of episodic acidification on fish predator-prey interactions: does weak acidification impair predator recognition? Sci Total Environ 439:62-66

Caldeira K, Wickett ME (2003) Oceanography: anthropogenic carbon and ocean $\mathrm{pH}$. Nature 425:365

Calosi PP, Bilton DT, Spicer JI (2007) The diving response of a diving beetle: effects of temperature and acidification. J Zool 273:289-297

Coors A, De Meester L (2008) Synergistic, antagonistic and additive effects of multiple stressors: predation threat, parasitism and pesticide exposure in Daphnia magna. J Appl Ecol 45:1820-1828

Crim RN, Sunday JM, Harley CG (2011) Elevated seawater $\mathrm{CO}_{2}$ concentrations impair larval development and reduce larval survival in endangered northern abalone (Haliotis kamtschatkana). J Exp Mar Biol Ecol 400:272-277

Dallinger R, Wang Y, Berger B, Mackay EA, Kägi JR (2001) Spectroscopic characterization of metallothionein from the terrestrial snail, Helix pomatia. Eur J Biochem 268:4126-4133

de la Haye KL, Spicer JI, Widdicombe S, Briffa M (2011) Reduced sea water pH disrupts resource assessment and decision making in the hermit crab Pagurus bernhardus. Anim Behav 82:495-501

de la Haye KL, Spicer Jl, Widdicombe S, Briffa M (2012) Reduced pH sea water disrupts chemo-responsive behaviour in an intertidal crustacean. J Exp Mar Biol Ecol 412:134-140

Dickey BF, McCarthy TM (2007) Predator and prey interactions between crayfish (Orconectes juvenilis) and snails (Physa gyrina) are affected by spatial scale and chemical cues. Invertebr Biol 126:57-66

Dillon RT Jr, Benfield EF (1982) Distribution of pulmonate snails in the New River of Virginia and North Carolina, USA: interaction between alkalinity and stream drainage area. Freshw Biol 12:179-186

Dixson DL, Munday PL, Jones GP (2010) Ocean acidification disrupts the innate ability of fish to detect predator olfactory cues. Ecol Lett 13:68-75

Dixson DL, Pratchett MS, Munday PL (2012) Reef fishes innately distinguish predators based on olfactory cues associated with recent prey items rather than individual species. Anim Behav 84:45-51

Ellis MM (1940) Pollution of the Coeur d'Alene river and adjacent waters by mine wastes. US Bureau of Fisheries Special Science Report

Fabry VJ, Seibel BA, Feely RA, Orr JC (2008) Impacts of ocean acidification on marine fauna and ecosystem processes. ICES J Mar Sci J Du Conseil 65:414-432

Farag AM, Woodward DF, Goldstein JN, Brumbaugh W, Meyer JS (1998) Concentrations of metals associated with mining waste in sediments, biofilm, benthic macroinvertebrates, and fish from the Coeur d'Alene River Basin, Idaho. Arch Environ Contam Toxicol 34:119-127 
Feely RA, Doney SC, Cooley SR (2009) Ocean acidification: present conditions and future changes in a high- $\mathrm{CO}_{2}$ world. Oceanography 22:36-47

Feely RA, Klinger T, Newton JA, Chadset M (2012) Scientific summary of ocean acidification in Washington State marine waters. NOAA/OAR Special Report

Ferrari MCO, Dixson DL, Munday PL, McCormick MI, Meekan MG, Sih A et al (2011) Intrageneric variation in antipredator responses of coral reef fishes affected by ocean acidification: implications for climate change projections on marine communities. Glob Change Biol 17:2980-2986

Finney DJ (1947) Probit analyses: a statistical treatment of the sigmoid response curve. Cambridge University Press, Cambridge

Fischer BB, Pomati F, Eggen RI (2013) The toxicity of chemical pollutants in dynamic natural systems: the challenge of integrating environmental factors and biological complexity. Sci Total Environ 449:253-259

Gaylord B, Hill TM, Sanford E, Lenz EA, Jacobs LA, Sato KN et al (2011) Functional impacts of ocean acidification in an ecologically critical foundation species. J Exp Biol 214:2586-2594

Gazeau F, Gattuso J, Greaves M, Elderfield H, Peene J, Heip CR et al (2011) Effect of carbonate chemistry alteration on the early embryonic development of the Pacific oyster (Crassostrea gigas). PLoS One 6:1-8

Gouin T, Armitage JM, Cousins IT, Muir DC, Ng CA, Reid L et al (2013) Influence of global climate change on chemical fate and bioaccumulation: the role of multimedia models. Environ Toxicol Chem 32:20-31

Hendriks IE, Duarte CM, Álvarez MM (2010) Vulnerability of marine biodiversity to ocean acidification: a meta-analysis. Estuar Coast Shelf Sci 86:157-164

Heugens EH, Hendriks AJ, Dekker T, Straalen NMV, Admiraal W (2001) A review of the effects of multiple stressors on aquatic organisms and analysis of uncertainty factors for use in risk assessment. CRC Critical Rev Toxicol 31:247-284

Hickey BM, Banas NS (2003) Oceanography of the U.S. Pacific Northwest Coastal Ocean and estuaries with application to coastal ecology. Estuaries 26:1010-1031

Holcombe GW, Phipps GL, Marier JW (1984) Methods for conducting snail (Aplexa hypnorum) embryo through adult exposures: effects of cadmium and reduced $\mathrm{pH}$ levels. Arch Environ Contam Toxicol 13:627-634

Hooper MJ, Ankley GT, Cristol DA, Maryoung LA, Noyes PD, Pinkerton KE (2013) Interactions between chemical and climate stressors: a role for mechanistic toxicology in assessing climate change risks. Environ Toxicol Chem 32:32-48

Hunter RD (1975) Growth, fecundity, and bioenergetics in three populations of Lymnaea palustris in upstate New York. Ecology 56:50-63

Hunter RD (1980) Effects of low pH and low calcium concentration on the pulmonate snail Planorbella trivolvis: a laboratory study. Can J Zool 68:1578-1583

IPCC (Intergovernmental Panel on Climate Change), Core Writing Team, Pachauri RK, Reisinger A (eds) (2007) Climate change 2007: synthesis report. Contributions of Working Groups I, II, and III to the Fourth Assessment Report of the Intergovernmental Panel on Climate Change, p 104, Geneva, Switzerland

Jugdaohsingh R, Campbell MM, Thompson RPH, McCrohan CR, White KN, Mucus Powell JJ (1998) Secretion by the freshwater snail Lymnaea stagnalis limits aluminum concentrations of the aqueous environment. Environ Sci Technol 32:2591-2595

Korsman T (1999) Temporal and spatial trends of lake acidity in northern Sweden. J Paleolimnol 22:1-15

Kroeker KJ, Kordas RL, Crim RN, Singh GG (2010) Meta-analysis reveals negative yet variable effects of ocean acidification on marine organisms. Ecol Lett 13:1419-1434

Lacoul PP, Freedman BB, Clair TT (2011) Effects of acidification on aquatic biota in Atlantic Canada. Environ Rev 19:429-460

Leduc A, Roh E, Harvey M, Brown G (2006) Impaired detection of chemical alarm cues by juvenile wild Atlantic salmon (Salmo salar) in a weakly acidic environment. Can J Fish Aquat Sci 63:2356-2363

Leduc AC, Roh E, Brown GE (2009) Effects of acid rainfall on juvenile Atlantic salmon (Salmo salar) antipredator behaviour: loss of chemical alarm function and potential survival consequences during predation. Mar Freshw Res 60:1223-1230

Lefcort H, Aguon MQ, Bond KA, Chapman KR, Chaquette R, Clark J et al (2002) Indirect effects of heavy metals on parasites may cause shifts in snail species compositions. Arch Environ Contam Toxicol 43:34-41
Lefcort H, Thomson SM, Cowles EE, Harowicz HL, Livaudais BM, Roberts WE et al (1999) Ramification of predator avoidance: predator and heavy metal mediated competition between tadpoles and snails. Ecol Appl 9:1477-1489

Lefcort H, Ammann E, Eiger SM (2000) Antipredatory behavior as an index of heavy-metal pollution? A test using snails and caddisflies. Arch Environ Contam Toxicol 38:311-316

Lefcort H, Freedman Z, House S, Pendleton M (2008) Hormetic effects of heavy metals in aquatic snails: is a little bit of pollution good? EcoHealth 5:10-17

Lefcort H, Vancura J, Lider E (2010) 75 Years after mining ends stream insect diversity is still affected by heavy metals. Ecotoxicology 19:1416-1425

Lefcort H, Wehner EA, Cocco PL (2013) Pre-exposure to heavy metal pollution and the odor of predation reduce the ability of snails to avoid stressors. Arch Environ Contam Toxicol 64:273-280

Leys C, Schumann S (2010) A nonparametric method to analyze interactions: the adjusted rank transform test. J Exp Soc Psychol 46:684-688

Lippert K, Gunn J, Morgan G (2007) Effects of colonizing predators on yellow perch (Perca flavescens) populations in lakes recovering from acidification and metal stress. Can J Fish Aquat Sci 64:1413-1428

Literary Digest (1926) Waste of coal and loss of public health. Lit Digest 90:80

Luís A, Bonet B, Corcoll N, Almeida S, Silva E, Figueira E et al (2014) Experimental evaluation of the contribution of acidic $\mathrm{pH}$ and Fe concentration to the structure, function and tolerance to metals ( $\mathrm{Cu}$ and $\mathrm{Zn}$ ) exposure in fluvial biofilms. Ecotoxicology 23:1270-1282

Machado A, Wood C, Bianchini A, Gillis P (2014) Responses of biomarkers in wild freshwater mussels chronically exposed to complex contaminant mixtures. Ecotoxicology 23:1345-1358

Manciocco A, Calamandrei G, Alleva E (2014) Global warming and environmental contaminants in aquatic organisms: the need of the etho-toxicology approach. Chemosphere 100:1-7

Manríquez P, Jara M, Mardones M, Navarro J, Torres R, Lardies M et al (2013) Ocean acidification disrupts prey responses to predator cues but not net prey shell growth in Concholepas concholepas (loco). PLoS One 8:1-10

Mason BJ (1992) Acid rain: its causes and its effects on inland waters. In: Mason BJ (ed) Science, technology, and society, series 8. Clarendon Press, Oxford; Oxford University Press, New York

Moe SJ, De Schamphelaere K, Clements WH, Sorensen MT, Van den Brink PJ, Liess M (2013) Combined and interactive effects of global climate change and toxicants on populations and communities. Environ Toxicol Chem 32:49-61

Neufeld J (1987) A summary of heavy metal contamination in the lower Coeur d'Alene river valley with particular reference to the Coeur d'Alene river wildlife management area. Idaho Dept. Fish and Game Publ., Coeur d'Alene, pp 1-37

Noyes PD, McElwee MK, Miller HD, Clark BW, Van Tiem LA, Walcott KC et al (2009) The toxicology of climate change: environmental contaminants in a warming world. Environ Int 35:971-986

$\varnothing$ kland J, Økland KA (1979) Use of fresh-water littoral fauna for environmental monitoring: aspects related to studies of 1000 lakes in Norway. In: Hytteborn $\mathrm{H}$ (ed) The Use of Ecological Variables in Environmental Monitoring pp 168-183. The National Swedish Environmental Protection Board, Report SNVPM, vol 1151, pp 1-348

Økland J, Økland KA (1986) The effects of acid deposition on benthic animals in lakes and streams. Experientia 42:471-486

Orr JL (2005) Anthropogenic ocean acidification over the twenty-first century and its impact on calcifying organisms. Nature 437:681

Rabe FW, Bauer SB (1977) Heavy metals in lakes of the Coeur d'Alene River Valley, Idaho. Northwest Sci 51:183-197

Ridolfi Engineering and Associates Inc (1993) Ridolfi Eng. and Assoc, Inc. Publications, Seattle

Schindler DW, Mills KH, Malley DF, Findlay DL, Shearer JA, Davies IJ et al (1985) Long-term ecosystem stress: the effects of years of experimental acidification on a small lake. Science 228:1395-1401

Schubauer-Berigan MK, Dierkes JR, Monson PD, Ankley GT (1993) pH-Dependent toxicity of $\mathrm{Cd}, \mathrm{Cu}, \mathrm{Ni}, \mathrm{Pb}$ and $\mathrm{Zn}$ to Ceriodaphnia dubia, Pimephales promelas, Hyalella azteca and Lumbriculus variegatus. Environ Toxicol Chem 12:1261-1266

Servos MR, Mackie GL (1986) The effect of short-term acidification during spring snowmelt on selected Mollusca in south-central Ontario. Can J Zool 64:1690-1695 
Sprenke KF, Rember WC, Bender SF, Hoffmann ML, Rabbi FF, Chamberlain VE (2000) Toxic metal contamination in the lateral lakes of the Coeur d'Alene River valley, Idaho. Environ Geol 39:575-586

Sullivan JT, Cheng TC (1975) Heavy metal toxicity to Biomphalaria glabrata (Mollusca: Pulmonata). Ann N Y Acad Sci 266:437-444

Turner AM, Chislock MF (2010) Blinded by the stink: nutrient enrichment impairs the perception of predation risk by freshwater snails. Ecol Appl 20:2089-2095

Vargas C, de la Hoz M, Aguilera V, Martín V, Manríquez P, Navarro J et al (2013) $\mathrm{CO}_{2}$-driven ocean acidification reduces larval feeding efficiency and changes food selectivity in the mollusk Concholepas concholepas. J Plankton Res 35:1059-1068 von Frisch K (1938) Zur psychologie des fisch-schwarmes. Die Naturwissenschaften 37:601-606

Wällstedt T, Borg H (2005) Metal burdens in surface sediments of limed and nonlimed lakes. Sci Total Environ 336:135-154

Watson S, Lefevre S, McCormick MI, Domenici P, Nilsson GE, Munday PL (2014) Marine mollusc predator-escape behaviour altered by near-future carbon dioxide levels. Proc R Soc B Biol Sci 281:20132377

Welsh PG, Skidmore JF, Spry DJ, Dixon DG, Hodson PV, Hutchinson NJ et al (1993) Effect of $\mathrm{pH}$ and dissolved organic carbon on the toxicity of copper to Larval Fathead Minnow (Pimephales promelas) in natural lake waters of low alkalinity. Can J Fish Aquat Sci 50:1356-1362

\section{Submit your manuscript to a SpringerOpen ${ }^{\odot}$ journal and benefit from:}

- Convenient online submission

- Rigorous peer review

- Immediate publication on acceptance

- Open access: articles freely available online

- High visibility within the field

- Retaining the copyright to your article

Submit your next manuscript at $>$ springeropen.com 